\title{
Hepatitis and Encephalitis due to Coxsackie Virus A9 in an Adult
}

\author{
Brigitte Moreau $^{\mathrm{a}} \quad$ Clare Bastedo $^{\mathrm{a}}$ Rene P. Michel ${ }^{\mathrm{b}}$ \\ Peter Ghali ${ }^{\mathrm{a}}$ \\ Departments of a Gastroenterology and bPathology, Royal Victoria Hospital, \\ McGill University, Montréal, Que., Canada
}

\section{Key Words}

Coxsackie virus · Hepatitis

\begin{abstract}
Coxsackie virus infection most commonly manifests itself in the neonatal period as a multisystem disease. This life-threatening neonatal infection has been recently treated with a new anti-picornaviral drug, pleconaril. In contrast, in adults Coxsackie virus is an uncommon source of hepatitis, but Coxsackie virus type B has been described in case reports to cause hepatitis. This is the first case report of hepatitis and encephalitis secondary to Coxsackie virus type A9 in an adult. This virus was found in a culture of the cerebrospinal fluid and was confirmed by PCR. The patient recovered completely without specific treatment.
\end{abstract}

\section{Introduction}

Viral hepatitis is a well-known cause of acute hepatitis in children and adults. Some patients may be asymptomatic while others may have signs and symptoms of acute hepatic injury such as abdominal pain, jaundice and malaise. More rarely, viral hepatitis may present as fulminant or acute hepatic failure. Among hepatotropic viruses that can cause acute hepatitis, the hepatitis A and B viruses are the most common worldwide. Others viruses, such as the herpes simplex virus, Epstein-Barr virus and human immunodeficiency virus, also result in severe hepatitis. Determining which virus is involved can be difficult and, therefore, it is not unusual that the cause of a severe acute hepatitis remains unknown. Some viruses, such as adenovirus or enterovirus, may have a seasonal presentation. In other cases, the clinical presentation and associated symptoms or findings may help narrow the search. 
The Coxsackie virus belongs to the enterovirus family and is spread by the fecal-oral and respiratory routes. $90 \%$ of enterovirus infections are asymptomatic or manifest simply as an undifferentiated febrile illness [1]. Age, gender and the host's immune status all influence the clinical presentation and infection severity. There are many presentations of Coxsackie virus infection. During a typical infection, fever lasts for 24-36 h and then declines with simultaneous appearance of nonpruritic, salmon-pink macules and papules on the face and upper trunk. The well-known hand, foot, mouth syndrome of Coxsackie virus, most commonly group A, affects mainly children. They have fever, oral vesicles and peripherally distributed small, tender cutaneous lesions. Petechial and purpuric rashes have also been described in Coxsackie virus A9 infections [2]. Meningitis and less frequently generalized or focal encephalitis may occur at all ages. Frank encephalitis is a very unusual manifestation of Coxsackie virus infection [3]. The enteroviruses account for only $11-22 \%$ of all cases of encephalitis that are proven to be viral [4]. Numerous serotypes have been implicated as causes of encephalitis, but Coxsackie virus types A9, B2 and $\mathrm{B} 5$ are reported most often. Both Coxsackie virus $\mathrm{A}$ and $\mathrm{B}$ peak during the summer, and Coxsackie virus $B$ has a minor peak in the winter.

23 serotypes from group A and 6 serotypes from group B have been identified. Isolation of Coxsackie virus in cell culture is the standard diagnostic method, but many group A Coxsackie viruses grow poorly or not at all in vitro [5]. However, PCR is more sensitive than cell culture. In liver biopsy tissue, enterovirus RNA has been demonstrated by in situ hybridization with a $3 \mathrm{H}$-labeled single-stranded complementary $\mathrm{RNA}$ probe prepared by in vitro transcription of a Coxsackie virus B3-derived cDNA fragment [6].

Most commonly, hepatic involvement with Coxsackie virus is seen in neonates, where it is part of a multisystemic illness [7]. The disease is usually severe with a high mortality rate. No specific treatment is available, but intravenous immune globulin has been used in life-threatening neonatal infections. More recently, 7 neonates were treated with the new anti-picornaviral drug, pleconaril [8]. This treatment may decrease viral load and enhance patient survival, but it cannot reverse the effects of extensive tissue damage. The rarer adult infection typically results in a self-limited febrile illness requiring no treatment. We report here a case of adult hepatitis and encephalitis due to Coxsackie virus A9.

\section{Case Report}

A 65-year-old man was admitted in August 2009 with a 2-week history of fatigue and occasional muscular calf pain followed by a new onset of fever, confusion, dizziness and unilateral hearing loss. He was known to have hypertension, chronic right leg deep vein thrombosis and atrial fibrillation. He was known also for follicular lymphoma and had received his last chemotherapy 5 months prior to admission. In the past, he had failed multiple cycles of various regimens of chemotherapy and had subsequently failed autologous stem cell transplantation. His medications included furosemide, K-Dur, colchicine, delatestryl and coumadin. He had visited the United States 2 weeks prior to admission. He had not eaten raw meat or drunk unpasteurised milk and he had not been in contact with animals.

Physical examination revealed a febrile patient $\left(38.6^{\circ} \mathrm{C}\right)$ with normal pulse, blood pressure and respiratory rate. He was oriented and did not appear to be in distress. He was not jaundiced. The only significant findings were a maculopapular rash on the trunk and pronounced hearing loss in the right ear. The abdomen was not tender nor was there any hepatosplenomegaly. The liver function studies at admission and during hospitalization are listed in table 1 . Other abnormal laboratory data on admission were: white blood cell count $1.35 \times 10^{9} / 1$, hemoglobin $101 \mathrm{~g} / \mathrm{l}$, platelets $41 \times 10^{9} / \mathrm{l}$, sodium $134 \mathrm{mEq} / \mathrm{l}$ and potassium $3.0 \mathrm{mEq} / \mathrm{l}$. A chest radiograph and CT scan of the brain were unremarkable. Abdominal 
ultrasound showed a normal liver except for focal fatty infiltration; there was no evidence of biliary obstruction or visible lymphoma. Further diagnostic tests including hepatitis A IgM, hepatitis C antibody, hepatitis B surface antigen and antibody, hepatitis B core antibody and monospot testing were all normal. Serum herpes group PCR, EBV IgM, CMV PCR, parvovirus B19 IgM and IgG, HIV and varicella zoster IgG were also ordered and were negative.

Since the patient was felt to be partially immunocompromised, he was started on acyclovir empirically to cover for herpes virus before the test results were known. Lumbar puncture was delayed because he was anticoagulated with warfarin. He also received ganciclovir, i.v. ceftriaxone, i.v. vancomycin and G-CSF as he became febrile and pancytopenic (of note, neutrophils $0.27 \times 10^{9} / \mathrm{l}$ ). He showed some clinical and biochemical improvement for the first 4 days of admission, but on day 5 he presented with a new decline in his cognitive status and a rise in liver enzymes, despite broad-spectrum antivirals and antibiotics. CMV PCR came back negative and ganciclovir was stopped. This evolution prompted suspicion that another etiology was the cause of the encephalitis and hepatitis. Serology for leptospirosis and VDRL were requested. The patient's anticoagulation was reversed and a lumbar puncture was performed. As he was persistently pancytopenic, a bone marrow biopsy was performed showing no evidence of hematologic malignancy. At the same time, a percutaneous liver biopsy was performed. It showed mild portal, interface and lobular lymphocytic and neutrophilic infiltration, with a moderate number of apoptotic bodies and numerous mitoses in hepatocytes, but no viral inclusions (fig. 1). There were no PAS-D-positive globules nor stainable iron and immunohistochemistry for cytomegalovirus and herpes simplex virus 1 and 2 was negative.

The patient improved clinically and his liver enzymes started to normalize. Finally, Coxsackie A9 was found in the cerebrospinal fluid culture and was confirmed by PCR. All empiric treatment was stopped and the patient was discharged on day 13 with improving liver function.

\section{Discussion}

In adults, Coxsackie virus is an uncommon source of hepatitis, but some cases of Coxsackie virus type B hepatitis have been reported. In 1962, the first case of Coxsackie B5 hepatitis in a pregnant woman was reported [9]. Four years later, a 19-year-old woman had acute hepatitis, pleurodynia and myocarditis as manifestations of Coxsackie virus type B3 infection [10]. This was the first report of pathological findings in a liver biopsy with hepatitis due to Coxsackie virus. In another case report [11], electron microscopy examination of liver biopsy demonstrated viral particles in a case of fatal hepatitis secondary to Coxsackie virus type B2 and B5. Two others case reports of acute liver failure due to Coxsackie virus type B have been published $[12,13]$. More recently, a Coxsackie virus type B4 anicteric hepatitis was also detected after a rise in antibody titers in the serum [14].

A generalized Coxsackie A9 infection with pericarditis, meningitis, pneumonitis and hepatitis in a neonate was reported in 1984 [15]. Coxsackie A9 virus was isolated from the cerebrospinal fluid, urine and feces of the infant. In the adult population, this is the first case report of hepatitis and encephalitis secondary to Coxsackie virus type A9 and may illustrate the way this particular infection manifests in susceptible adults.

A review of the epidemiology of Coxsackie virus infection in Taiwan revealed that Coxsackie virus A was more prevalent, but that patients with type B were more likely to have complications [16]. Of 265 patients with Coxsackie virus A infection, only $5.3 \%$ had type A9 infection; most presented with fever, skin or ENT manifestations and none of these patients had evidence of hepatic necrosis (AST $>3$ times normal).

Our case suggests that the natural history in an immunocompromised host may be different and more virulent. A higher index of suspicion for atypical viral infections as a 
cause of hepatitis may be warranted, and perhaps a more extensive evaluation should be carried out. It is also unknown whether, in severe cases without improvement, additional therapies such as intravenous immune globulin should be given.

\section{Disclosure Statement}

The authors have no conflict of interest.

Table 1. Liver function studies during hospitalization

\begin{tabular}{|c|c|c|c|c|c|c|c|}
\hline & \multicolumn{7}{|c|}{ Hospitalization days } \\
\hline & 1 & 3 & 5 & 6 & 7 & 9 & 12 \\
\hline ALT, IU/l & 1,202 & 719 & 1,375 & 1,634 & 1,105 & 582 & 179 \\
\hline AST, IU/l & 1,418 & 168 & & 1,530 & & 146 & 26 \\
\hline Alk Phos, IU/l & 120 & 143 & 154 & 174 & 183 & 158 & 138 \\
\hline Total bilirubin, $\mu \mathrm{mol} / \mathrm{l}$ & 44 & 25 & 44 & 79 & 71 & 36 & 26 \\
\hline Direct bilirubin, $\mu \mathrm{mol} / \mathrm{l}$ & 13 & & & 36 & 33 & 13 & 8 \\
\hline INR & 2.98 & & 2.97 & 1.68 & 1.22 & & \\
\hline $\mathrm{LDH}, \mathrm{IU} / \mathrm{l}$ & 1,554 & & 2,098 & & 344 & 212 & 191 \\
\hline
\end{tabular}




\begin{tabular}{r|l|l|l}
$\begin{array}{r}\text { Case Reports in } \\
\text { Gastroenterology }\end{array}$ & $\begin{array}{l}\text { Case Rep Gastroenterol 2011;5:617-622 } \\
\text { Dol: 10.1159/000333135 }\end{array}$ & $\begin{array}{l}\text { Published online: } \\
\text { October 10, 2011 }\end{array}$ & $\begin{array}{l}\text { O 2011 S. Karger AG, Basel } \\
\text { ISSN 1662-0631 } \\
\text { www.karger.com/crg }\end{array}$ \\
\hline
\end{tabular}
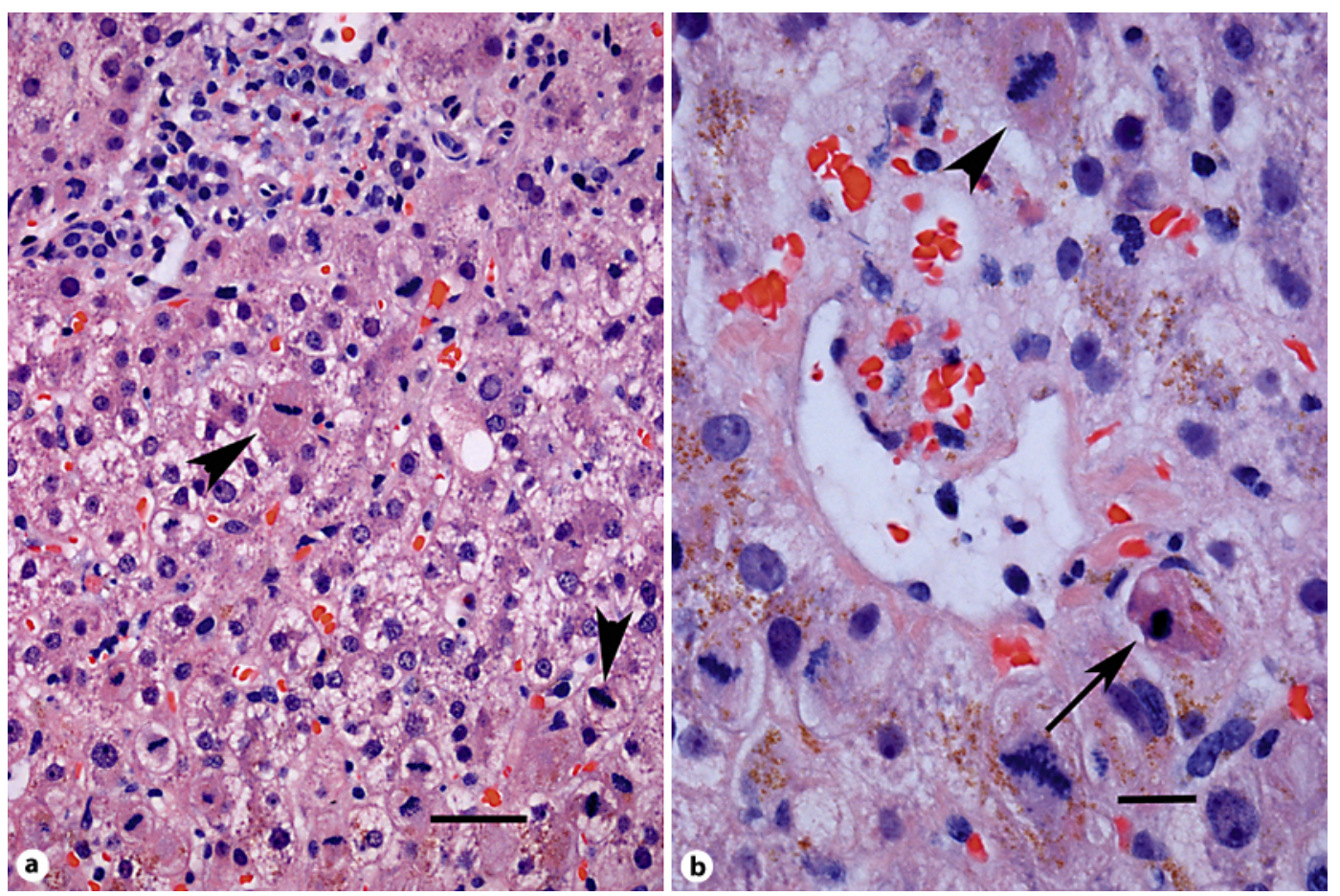

Fig. 1. a Medium power light photomicrograph showing portal area (top) with mild inflammation, disarray and mitoses (arrowheads). Hematoxylin and eosin, $\times 200$. Scale bar $=30 \mu \mathrm{m}$. b Higher power of small central vein and surrounding hepatocytes with mitoses (arrowhead) and apoptotic body (arrow). Hematoxylin and eosin, $\times 400$. Scale bar $=15 \mu \mathrm{m}$.

\section{References}

1 Kogon A, Spigland I, Frothingham TE, et al: The virus watch program: a continuing surveillance of viral infections in metropolitan New York families. VII. Observations on viral excretion, seroimmunity, intrafamilial spread and illness association in coxsackie and echovirus infections. Am J Epidemiol 1969;89: 51-61.

2 Frothingham TE: ECHO virus type 9 associated with three cases simulating meningococcemia. N Engl J Med 1958;259:484-485.

-3 Fowlkes AL, Honarmand S, Glaser C, et al: Enterovirus-associated encephalitis in the California encephalitis project, 1998-2005. J Infect Dis 2008;198:1685-1691.

4 Meyer HM Jr, Johnson RT, Crawford IP, et al: Central nervous system syndromes of 'vital' etiology. A study of 713 cases. Am J Med 1960;29:334-347.

5 American Academy of Pediatrics: Enterovirus (nonpoliovirus) infections; in Pickering LK, Baker CJ, Long SS, Mcmillan JA (eds): Red Book 2006 Report of the Committee on Infectious Diseases. American Academy of Pediatrics, 2006, pp 284-285.

6 Clavell M, Barkemeyer B, Martinez B, Craver R, Correa H, Gohd R, Schmidt-Sommerfeld E: Severe hepatitis in a newborn with coxsackievirus B5 infection. Clin Pediatr (Phila) 1999;38:739-741.

7 Wang SM, Liu CC, Yang YJ, Yang HB, Lin CH, Wang JR: Fatal Coxsackievirus B infection in early infancy characterized by fulminant hepatitis. J Infect 1998;37:270-273.

8 Bryant PA, Tingay D, Dargaville PA, Starr M, Curtis N: Neonatal Coxsackie B virus infection - a treatable disease? Eur J Pediatr 2004;163:223-228.

-9 O'Shaughnessey WJ, Buechner HA: Hepatitis associated with a Coxsackie B5 virus infection during late pregnancy. JAMA 1962;179:71-72. 
10 Sun NC, Smith VM: Hepatitis associated with myocarditis. Unusual manifestation of infection with Coxsackie virus group B, type 3. New Eng J Med 1966;274:190-193.

-11 Gregor GR, Geller SA, Walker GF, Campomes BA: Coxsackie hepatitis in an adult, with ultrastructural demonstration of the virus. Mt Sinai J Med 1975;42:575-580.

12 Read RB, Ede RJ, Morgan-Capner P, et al: Myocarditis and fulminant hepatic failure from coxsackevirus B infection. Postgrad Med J 1985;61:749-752.

13 Archer JS: Acute liver failure in pregnancy. J Reprod Med 2001;46:137-140.

14 Delic D, Nesic Z, Prostran M, Simonovic J: Anicteric hepatitis in an adult associated with Coxsackie B4 virus infection. Infection 2006;34:236-237.

15 Talsma M, Vegting M, Hess J: Generalised Coxsackie A9 infection in a neonate presenting with pericarditis. Br Heart J 1984;52:683-685.

16 Yen FB, Chang LY, Kao CL, Lee PI, Chen CM, Lee CY, Shao PL, Wang SC, Lu CY, Huang LM: Coxsackieviruses infection in northern Taiwan - epidemiology and clinical characteristics. J Microbiol Immunol Infect 2009;42:38-46. 